\title{
Return rates of nest box breeding Pied Flycatchers Ficedula hypoleuca to their breeding site in subalpine birch forest in Swedish Lapland, during 1965-2018
}

\author{
Andelar holkhäckande svartvit flugsnappare Ficedula \\ hypoleuca som återvände till häckningsplatsen \\ i fjällbjörkskog i Lappland, 1965-2018
}

\author{
N Erik I Nyholm
}

Department of Ecology and Environmental Science, Umeå University, 90187 Umeå, Sweden | erik.nyholm@umu.se

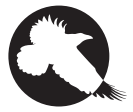

RETURN RATES of 4,178 female and 1,565 male breeding Pied Flycatchers ringed in 1965-2017 were studied near the species' upper elevation and climatic limit in northern Sweden. Female return rate was $7.5 \%$ in the season subsequent to the first breeding season. Having returned once, $38 \%$ continued to return the next three seasons. Corresponding return rates of males were $27 \%$ and $39 \%$. Female return rate decreased with more than $30 \%$ during the study period whereas that of males did not decrease. This difference was probably due to increased mortality during the non-breeding season that selectively struck females after the 1970s. Local factors affected return rates in both sexes. Return rate was positively correlated with breeding success in females but negatively in males, whereas it was correlated with nest predation in the opposite way. Predation by mustelids accounted for a significant part of female return rate. Females that had returned once were continuously faithful to the former breeding site. Males showed faithfulness only after having returned twice.

Keywords: breeding site fidelity | breeding success | predation | survival 


\section{Introduction}

The Pied Flycatcher Ficedula hypoleuca has relatively recently expanded its distribution range northwards to become a frequent breeder in an increasing part of Scandinavia during the two latest centuries (cf. Lundberg \& Alatalo 1992). Subalpine birch forest represents the most peripheral northern habitat within the range of the species. Here the populations experience strongly varying and harsh climatic conditions, which influence the breeding course and success. Furthermore, varying predation pressure by small mustelids as a consequence of the typically occurring cyclic small rodent populations adds to the unpredictability of the habitat. In this habitat, the studied Pied Flycatcher population usually failed to produce enough fledglings to be self-sustainable (Nyholm 2011).

A study of breeding area fidelity of female and male Pied Flycatchers at the same site in 1965-1976 (Nyholm \& Myhrberg 1983) showed that both sexes were less faithful to their former breeding site than populations more southerly in Fennoscandia, in Great Britain, and on the European continent (Lundberg \& Alatalo 1992, Sanz 2001). The present, much extended study deals with return rates calculated from high annual numbers of ringed breeding males and females over 27 and 54 seasons, respectively. This opens for a more differentiated view of the return rates shown by the sexes, and for analyses of underlying causes of the variation in return rates at a peripheral northern breeding site.

\section{Material and methods}

The study was performed in 1965-2018 in a nest box breeding population of Pied Flycatcher in subalpine birch forest at about 500 to 600 m.a.s.l. on south-facing slopes of the mountains Gájssietjåhkka and Vállienjuoná, 5-10 km west of Ammarnäs at approximately $65^{\circ} 58^{\prime} \mathrm{N}, 16^{\circ} 05^{\prime} \mathrm{E}$. The habitat (see Appendix 1) is a predominantly rich type of forest, with luxuriant undergrowth of herbs ("meadow type"). In dryer parts, the forest turns into a "heath type". The habitats of the nest box plots, which were unchanged during the study period, are similar to that of surrounding mountain slopes.

The study comprises 4,178 breeding females ringed in 1965-2017 (Appendix 2), and 1,565 males ringed in 1965-1990 (Appendix 3). As the return rate of nestlings from the study site was low (1\%; Nyholm 1986), un- ringed adults are considered as being of unknown age $(2 \mathrm{CY}+)$ and recruited from elsewhere. The sample of females and males do not include ringed individuals that were killed by predation, or found dead for unknown reason during their first breeding season in the study area ( 54 females and 2 males). Included are, however, fifteen returning females (eight during their second; four in their third; two in their fourth, and one in its fifth breeding season), and two males (during their second season) that were found dead. The appendices also present the yearly numbers of breeding, captured and returning individuals as well as the number calculated to be returning (corrected value; see below).

A nest was recorded as a breeding attempt when it contained at least one egg. Nest predation was revealed by occurrences of excess feathers, and/or wings or legs bitten off within and/or close to the nest box.

The individuals that were ringed comprised a random proportion of the breeding population. To get closest to the "correct" number of returning individuals, e.g. from the year when ringed (Year X) to the subsequent year (Year X+1), a correction factor was introduced. This was calculated as the ratio of number of breeding individuals in Year $\mathrm{X}+1$ over the number of captured birds in Year X+1 (cf. Nyholm \& Myhrberg 1983). When calculating the correction factors for males, the yearly breeding numbers were set $9 \%$ lower than for the females because of polygyny in the study area (cf. Nyholm 1984). The corrected returning numbers, i.e. the correction factor times the verified numbers of returning individuals ringed in Year X, were used when to estimate the annual return rates.

The females were to about 90 percent caught and ringed during the incubation period, and the remaining ones when feeding their nestlings. The males were to more than 95 percent ringed when feeding the nestlings. This means that the return rates refer to females and males with complete clutches. That also apply for the rates of nest predation, nest abandonment, breeding success used in calculations.

As a part of the breeding males and females remained unringed, these might incorrectly be assigned as first-time breeders in the study area if caught in a later year. These individuals were, however, too few to interfere substantially with the results of the study (cf. Nyholm 1983). 

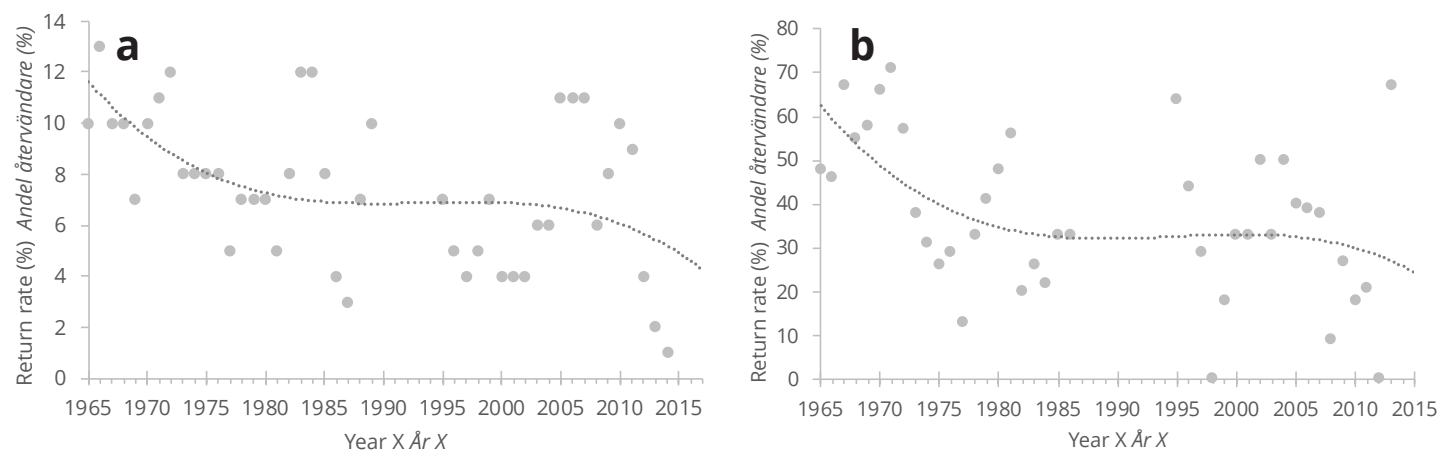

FIGURE 1. Three-year running average return rate (\%) of Pied Flycatcher females (a) from Year $X$ to Year $X+1$ (ringed Year X 1965-2016), and (b) from Year $X+1$ to Year $X+2$ (ringed Year $X 1965-2013$ ). Note different scales of the $y$-axes. (a) Linear regression: $r^{2}=0.10 ; b=-0.0024 ; p=0.024$; equation of line: $Y=5.03-0.0024 X$ (not shown). When back transforming the values to percentages, the return rate decreased on average by $0.15 \%$ per year. The best fit is given by the cubic regression model shown in the diagram (dotted line; $\left.r^{2}=0.12\right)$. $(\mathbf{b})$ Linear regression: $r^{2}=0.078$; $b=-0.0072 ; p=0.073$; equation of the line: $Y=14.9-0.0072 X$ (not shown). When back transforming the values to percentages, the return rate decreased on average by $0.08 \%$ per year. Best fit is given by a cubic regression model (dotted line; $r^{2}=0.16$ ).

- Löpande treårsmedelvärden av andel svartvit flugsnapparhonor som återvände (a) från år X till år X+1 (ringmärkta år X 1965-2016) respektive (b) från från år X+1 till år X+2 (ringmärkta år X 1965-2013). Notera olika skalor på $y$-axlarna. (a) Linjär regression: $r^{2}=0,10 ; b=-0,0024 ; p=0,024 ;$ ekvation: $Y=5,03-0,0024 X$ (visas ej). Andelen minskade med 0,15\% per år. Den bästa regressionen var en kubisk modell (streckad linje; $\left.r^{2}=0,12\right)$. (b) Linjär regression: $r^{2}=0,078 ; b=-0,0072 ; p=0,073$; ekvation: $Y=14,9-0,0072 X$ (visas ej). Andelen minskade med 0,08\% per år. Den bästa anpassningen av regressionen gav den kubiska modell som visas i diagrammet (streckad linje; $r^{2}=0,16$ ).

The analyses are often based on time series in which the variables are not always independent because a value any given year may be partly dependent on its value the preceding year. Still, I have used correlation and regression tests (linear, quadratic, and cubic), as they are considered sufficient for testing the processes that have occurred. All proportions were arcsine square root transformed before statistical testing. All significance tests (Pearson's correlation and Regression analyses) are two-tailed, and the corrected $\mathrm{r}^{2}$ values are presented. The $\chi^{2}$ tests were performed using Microsoft Excel and other tests by IBM SPSS 24.

\section{Results}

\section{RETURN RATE OF ONE-TIME BREEDERS}

The return rate of breeding females from the season they were ringed (Year X) to the next (Year X+1) was on average $7.5 \%$ in $1966-2018$. The range of the yearly variation of return rate was considerable, $0-19 \%$ (Table 1).

A significantly decreasing trend of the yearly return rate of females occurred. The decrease was especially obvious at the beginning of the study as illustrated by the fact that the cubic regression model described the trend best (Figure 1a).
The return rate of males from the year they were ringed (Year X) to the next (Year X+1), in 1966-1991, was on average $27 \%$, with a wide range of yearly variation, $0-53 \%$ (Table 2 ). The only year without any verified returning males was 1988, when only 13 out of 141 males were controlled. Apart from that year, the return rate range was $12-53 \%$.

The return rates of the males ringed in 1965-1990 showed a significantly increasing trend (Linear regression: $\left.\mathrm{r}^{2}=0.27 ; b=0.007 ; \mathrm{p}<0.008\right)$. In comparison, the return rate for females tended instead to decrease $(p=0.07)$, during the same period. Moreover, the yearly variations of the return rates of males and females were negatively correlated $(b=-0.38 ; p=0.04)$.

Three highly variable local factors connected to breeding during Year $\mathrm{X}$ were studied for their relation to the variations of return rates from Year $\mathrm{X}$ to $\mathrm{X}+1$ of males and females: Breeding success (yearly mean number of fledglings, nest predation rate (a proxy for numbers of predators at the breeding site), and rate of nest abandonment (excl. predated nests; a proxy for adverse weather conditions) of complete clutches (Table 3). The correlation between return rate of females in Year X+1 (1966-2018) and these local factors in Year X was significantly positive for breeding success, negative for nest predation rate (Table 3 ), and negative 
TABLE 1. Return rate from year $X$ to year $X+1$ of Pied Flycatcher females ringed in 1965-2016.

- Andel återvändande svartvit flugsnapparhonor från år X till $X+1$, ringmärkta 1965-2016.

\begin{tabular}{rrrrrrrr}
\hline Year & & Year & \multicolumn{3}{c}{ Year } & Year \\
ArX & $\%$ & ArX & $\%$ & ArX & $\%$ & ArX & $\%$ \\
\hline 1965 & 6 & 1979 & 4 & 1993 & - & 2007 & 19 \\
1966 & 15 & 1980 & 11 & 1994 & - & 2008 & 7 \\
1967 & 9 & 1981 & 4 & 1995 & 4 & 2009 & 2 \\
1968 & 13 & 1982 & 5 & 1996 & 14 & 2010 & 10 \\
1969 & 8 & 1983 & 5 & 1997 & 3 & 2011 & 11 \\
1970 & 9 & 1984 & 13 & 1998 & 0 & 2012 & 9 \\
1971 & 5 & 1985 & 18 & 1999 & 8 & 2013 & 5 \\
1972 & 18 & 1986 & 8 & 2000 & 7 & 2014 & 0 \\
1973 & 11 & 1987 & 0 & 2001 & 5 & 2015 & 0 \\
1974 & 10 & 1988 & 0 & 2002 & 0 & 2016 & 3 \\
1975 & 3 & 1989 & 8 & 2003 & 6 & 2017 & 0 \\
1976 & 13 & 1990 & 9 & 2004 & 5 & & \\
1977 & 8 & 1991 & 15 & 2005 & 8 & & \\
1978 & 4 & 1992 & - & 2006 & 5 & & \\
\hline
\end{tabular}

(though non-significantly) for rate of abandoned nests. The correlations between these factors in Year X and the female yearly return rates in Year X+1 in 1966-1991 were similar to those in 1966-2018. In males the yearly variation of return rate in 1966-1991 showed an opposite correlation pattern to that of the females, being significantly negative to the variation of fledgling numbers, significantly positive to the rate of nest predation, and non-significantly positive to nest abandonment (Table 4).

Stepwise multiple regression analysis of the variation of female return rates, and these partly inter-dependent local factors as independent variables, revealed that in 1965-2017 predation rate alone accounted for a significant part of the yearly return rate variation (Table 5). The other factors, breeding success and nest abandonment, had non-significant influence on the variation of female return rate.

Though the predation rate on average was relatively low (see above) in 1965-1990, it even then significantly accounted for the variation of yearly return rates in females as well as in males. In females breeding success, and in males rates of nest abandonment showed close to significant influence on return rate (Table 5).

\section{RETURN RATE OF MULTIPLE-SEASON BREEDERS}

In general, female return rate from Year $\mathrm{X}+1$ to Year
$\mathrm{X}+2$ tended to decrease $(\mathrm{b}=-0.007 ; \mathrm{p}=0.073$; Figure $1 b)$. As with females returning after one breeding season, the return rate of females returning multiple times were best described by a cubic function (Figure 1b).

The weighted mean return rate of females ringed in 1965-2014 that returned to breed in the study area in the Years $\mathrm{X}+2-\mathrm{X}+4$, was $38 \%$ (Table 6). The return rates in the Years $X+2$ and $X+3$ were similar, while the rate of females returning in Year $\mathrm{X}+4$ was close to significantly lower $(\mathrm{p}<0.09)$.

When splitting up the study period, I found that the return rate decreased significantly over time, from $44 \%$ for females ringed in 1965-1976 to $29 \%$ in 2004-2014. The highest long-term mean return rate, $53 \%$, was shown from Year $\mathrm{X}+1$ to $\mathrm{X}+2$ by females ringed in 1965-1976. For those ringed later, in 1977-2014, the mean return rate was significantly lower, $32 \%$ ( $p<0.001$; Table 6).

The return rates of the females ringed in 1965-1976 decreased significantly with age from $4 \mathrm{CY}+($ Year $\mathrm{X}+2)$ to $5 \mathrm{CY}+$ and $6 \mathrm{CY}+($ Years $\mathrm{X}+3$ and $\mathrm{X}+4 ; 53 \%$ to $37 \%$ and $30 \%$, respectively).

The weighted mean rates of females and males ringed in 1965-1983 that returned in Years X+2 to X+4 were similar, $41 \%$ and $39 \%$, respectively (Table 6 ). The mean return rate of males increased significantly from Year X+1 $(25 \%)$, over X+2 (35\%) to Year X+3 (62\%),

TABLE 2. Return rate from year $X$ to year $X+1$ of Pied Flycatcher males ringed in 1965-1990.

- Andel återvändande svartvit flugsnapparhannar från år X till år X+1, ringmärkta 1965-1990.

\begin{tabular}{llll}
\hline Year år X & $\%$ & Year år X & $\%$ \\
\hline 1965 & 21 & 1978 & 46 \\
1966 & 12 & 1979 & 24 \\
1967 & 32 & 1980 & 28 \\
1968 & 24 & 1981 & 25 \\
1969 & 20 & 1982 & 33 \\
1970 & 23 & 1983 & 26 \\
1971 & 21 & 1984 & 12 \\
1972 & 23 & 1985 & 22 \\
1973 & 26 & 1986 & 34 \\
1974 & 29 & 1987 & - \\
1975 & 22 & 1988 & 50 \\
1976 & 39 & 1989 & 37 \\
1977 & 22 & 1990 & 53 \\
\hline
\end{tabular}


TABLE 3. Annual number of Pied Flycatcher fledglings per clutch and rates of predation or abandonment of complete clutches of eggs or nestlings.

- Årliga antal flygga svartvit flugsnapparungar per kull och andelar bon med kompletta kullar med ägg eller ungar som rövades eller övergavs.

\begin{tabular}{|c|c|c|c|}
\hline Period & Parameter & Median & Range Vidd \\
\hline \multirow[t]{3}{*}{$1965-2017$} & $\begin{array}{l}\text { No of fledglings } \\
\text { Antal flygga ungar }\end{array}$ & 2.7 & $0.59-5.06$ \\
\hline & $\begin{array}{l}\text { Nest predation rate }(\%) \\
\text { Andelen prederade bon }\end{array}$ & 7 & $0-56$ \\
\hline & $\begin{array}{l}\text { Nest abandonment rate (\%) } \\
\text { Andelen övergivna bon }\end{array}$ & 20 & $3-72$ \\
\hline \multirow[t]{3}{*}{ 1965-1990 } & $\begin{array}{l}\text { No of fledglings } \\
\text { Antal flygga ungar }\end{array}$ & 2.9 & $0.59-5.06$ \\
\hline & $\begin{array}{l}\text { Nest predation rate }(\%) \\
\text { Andelen prederade bon }\end{array}$ & 2 & $0-56$ \\
\hline & $\begin{array}{l}\text { Nest abandonment rate }(\%)^{\text {a }} \\
\text { Andelen övergivna bon }\end{array}$ & 21 & $3-72$ \\
\hline
\end{tabular}

a For unverified reason. Av okänd anledning.

and thereafter decreased in Year X+4 (42\%). With the females, it was at highest already in Year X+2 (48\%). The return rate of males from Year $\mathrm{X}+1$ to $\mathrm{X}+2$ was thereby significantly lower than for females $(p<0.006)$, but from Year $\mathrm{X}+2$ to $\mathrm{X}+3$ it was higher $(\mathrm{p}<0.001$; Table 6).

\section{Discussion}

\section{RETURN RATE BETWEEN}

\section{THE FIRST AND SECOND BREEDING SEASON}

The males and females that returned to their former breeding site are those having survived the non-breeding season and are faithful to that site. Those that did not return, either had died, or were alive but bred somewhere else. The Pied Flycatcher is certainly one of the most studied species as to breeding territory fidelity, ever since 1940 s and over a great part of its distribution range (von Haartman 1951, Leivits \& Vilbaste 1990, Lundberg \& Alatalo 1992, Järvinen 1993, Sanz 2001, Kern et al. 2014).

Several long-term studies show that the return rate of Pied Flycatchers to their first breeding site the subsequent year decreases from southern to northern latitudes. That trend is similar for the sexes but is especially pronounced in females (cf. Lundberg \& Alatalo 1992). The most extensive review of the regional variation of local return rates of Pied Flycatchers concerns breeding females, of which about $40 \%$ returned for a second breeding season in central Spain, while less than $10 \%$ returned in northern Fennoscandia (Sanz 2001).

In the present study, the return rate of females, from their first breeding season to the next, was on average $7.5 \%$ in $1966-2018$. This fits the pattern showing low return rate at far northern latitudes.

Males usually show higher return rates than females do (cf. Lundberg \& Alatalo 1992). In the present study, the return rate of the males in 1966 to 1991 was on average $27 \%$, which is lower than usually reported from more southerly latitudes. During the same period on average $8.4 \%$ of the females returned the subsequent season to breed a second time in the study area.

The variation of male return rates over 1966-1991 showed a significantly increasing trend, whereas in females, the trend was instead significantly decreasing. Moreover, the yearly return rates of the sexes were significantly negatively correlated. These dissimilarities indicate that factors that were influential on return rates, external or local at the breeding site, affected the sexes differently.

Breeding success, nest predation rate, and rate of nest abandonment (excl. predated nests) were, partly interdependent, local factors studied for their relation to the variations of return rates of males and females from Year $\mathrm{X}$ to $\mathrm{X}+1$. The latter factors did strongly influence breeding success and contributed to prevent the Pied Flycatcher population to be self-reproducing in the long term (Nyholm 2011). On average, only 2.7 fledglings per breeding pair were produced in 1965-2017. The northerly position and the altitude of the study area implied increased risk of hazardous weather conditions during the breeding seasons. The range of the yearly mean temperature in June varied between 7.4 to $14.4^{\circ} \mathrm{C}$ and the yearly rates of nest abandonments correlated significantly with this temperature (Nyholm 2011). Nest predation, by small mustelids, regularly affected the breeding of Pied Flycatchers. The variation in predation rate was typically related to the density of the cyclic 
small rodent populations. After mid-198os, obviously favourable conditions existed for the development of very high mustelid population densities, followed by very high predation pressure on their alternative prey species, i.e. birds in the study area (cf. Nyholm 2011). Thus in $1965-1986$ as a mean $6 \%$ of the clutches were predated, whilst $26 \%$ in 1991-2017.

These local factors influenced the yearly variations of female and male return rates. Notably, however, the return rates of the sexes were differently influenced (Table 4). Kern et al. (2014) suggested similarly, from a more limited study in Wales, that females struck by nest predation were less likely to return the subsequent year, and that the opposite was true for males. In contrast to the present study, however, the Welsh study showed significantly positive relationship between breeding success and return rate of females as well as males.

The multiple regression analysis revealed that predation rate alone accounted for a significant part of the female return rate variation from 1965-2017 (Table 5). As no ringed female included in the calculations were killed at nest predation, it seems probable that the females' readiness to return was affected by the mere occurrence of small mustelids at their breeding sites, which varied as reflected by the nest predation rates.

Notably, also in 1965-1986, when the mustelid populations varied within limits probably more normal for the study area, the female return rate variation was in the first hand associated with the variation in nest predation rate $(b=-0.21 ; p<0.01)$. Also the rate of nest abandonment, the other local factor causing breeding failure, did then account significantly for the return rate variation $(b=-016 ; p=0.031)$. Together these two factors explained $43 \%$ of the variation in return rates. This indicates that the yearly variation of the female return rate was negatively related to frequency of total clutch/ brood loss, rather than to reduced numbers of fledglings. The male return rate variation was insignificantly explained by the studied local factors in 1965-1986.

In 1965-1990, predation rate did account significantly for the variation of the male, as well as the female return rates (Table 5). However, whereas negatively related to female return rates it had a positive effect on the return rates of the males (Table 5). It is reasonable to believe that males met with nest predators to a lower degree than the females did, and thus got less directly affected by them. Rather, they might be influenced, here positively, by what nest predation implies e.g. reduced breeding effort. Askenmo (1979) demonstrated experimentally, in southern Sweden, that clutch enlargements caused reduced return rate of Pied Flycatcher males in subsequent breeding seasons. The interpretation was that the extra reproductive effort invested in a large brood led to increased inter-seasonal mortality rate. An explanation to the negative relation between the fledgling numbers and return rate of the males could be that the feeding efforts even at normal brood sizes were big enough to affect the males' survival at the prevailing, frequently harsh, breeding conditions at the actual subalpine site. High yearly losses of nestlings in 1965-1990 (median 14\%; range 1-72\%; predated and abandoned broods excluded) indicated frequent great problems to satisfy the broods. There was also a negative, though not significant, relation between the yearly average

TABLE 4. The annual Pied Flycatcher female and male return rates (\%) from Year $X$ to Year $X+1$ in relation to mean number of fledglings, and rates of predated or abandoned ${ }^{a}$ complete clutches in Year X. The statistics presented are the slope (beta coefficient; b) and significance level ( $p)$.

- Årliga andelar honor och hannar av svartvit flugsnappare som återvände från år X till år X+1 i relation till medelantal flygga ungar och andelar bon som rövades respektive övergavsa år X. De värden som anges är sambandets lutning (betakoefficienten; b) och signifikansnivån (p).

\begin{tabular}{|c|c|c|c|c|c|c|c|c|}
\hline \multirow[b]{2}{*}{$\begin{array}{l}\text { Year X } \\
\text { ArX }\end{array}$} & \multirow[b]{2}{*}{$\begin{array}{l}\text { Sex } \\
\text { Kön }\end{array}$} & \multirow[b]{2}{*}{$\begin{array}{l}\text { Sample size } \\
\text { Antal }\end{array}$} & \multicolumn{2}{|c|}{$\begin{array}{l}\text { Fledglings (N) } \\
\text { Flygga }(N)\end{array}$} & \multicolumn{2}{|c|}{$\begin{array}{l}\text { Predated nests (\%) } \\
\text { Prederade bon (\%) }\end{array}$} & \multicolumn{2}{|c|}{$\begin{array}{c}\text { Abandoned nests (\%) }{ }^{a} \\
\text { Övergivna bon (\%) a }\end{array}$} \\
\hline & & & $b$ & $\mathrm{p}$ & $b$ & $p$ & $b$ & $p$ \\
\hline 1965-2017 & 우 & 50 & 0.041 & 0.037 & -0.29 & $<0.001$ & -0.06 & 0.60 \\
\hline 1965-1990 & ㅇ & 26 & 0.053 & 0.002 & -0.36 & $<0.001$ & -0.19 & 0.12 \\
\hline 1965-1990 & $0^{7}$ & 25 & -0.037 & 0.002 & 0.25 & 0.006 & 0.18 & 0.12 \\
\hline
\end{tabular}

a For unverified reason. Av okänd anledning. 
TABLE 5. Multiple stepwise regression analysis of influences of the annual variations of mean number of fledglings, nest predation rate, and rate of nest abandonments ${ }^{a}$ of complete clutches in Year $X$ on the annual return rates in Year $X+1$ (\%) of females and males, respectively, during 1965-2017 and 1965-1990. Variables with $p<0.1$ are presented in the main table.

- Multipel stegvis regressionsanalys av hur årliga variationer av medelantal flygga ungar, andel prederade bon och övergivna bon år $X$ påverkade andelarna honor respektive hannar som återvände år X+1 under 1965-2017 och 1965-1990. Variabler med p<0,1 visas.

\begin{tabular}{|c|c|c|c|c|c|c|}
\hline $\begin{array}{l}\text { Year X } \\
\text { ArX }\end{array}$ & $\begin{array}{l}\text { Sex } \\
\text { Kön }\end{array}$ & $\begin{array}{l}\text { Independent variable } \\
\text { Oberoende variabel }\end{array}$ & $r^{2}$ & $b$ & $\mathrm{t}$ & $\mathrm{p}$ \\
\hline 1965-2017 & ㅇ & $\begin{array}{l}\text { Nest predation rate }{ }^{b} \\
\text { Andelen prederade bon }{ }^{b}\end{array}$ & 0.32 & -0.29 & -4.74 & $<0.001$ \\
\hline \multirow[t]{2}{*}{ 1965-1990 } & 우 & $\begin{array}{l}\text { Nest predation rate }{ }^{c} \\
\text { Andelen prederade bon }{ }^{c}\end{array}$ & 0.60 & -0.24 & -3.09 & 0.005 \\
\hline & & $\begin{array}{l}\text { No of fledglings } \\
\text { Antal flygga ungar }\end{array}$ & & 0.026 & 1.87 & 0.074 \\
\hline \multirow[t]{2}{*}{ 1965-1990 } & $0^{7}$ & $\begin{array}{l}\text { Nest predation rate }{ }^{d} \\
\text { Andelen prederade bon }{ }^{d}\end{array}$ & 0.37 & 0.24 & 3.07 & 0.006 \\
\hline & & $\begin{array}{l}\text { Proportion abandoned nests } \\
\text { Andelen övergivna bon }\end{array}$ & & 0.16 & 1.73 & 0.098 \\
\hline
\end{tabular}

axcluding predated nests. Exklusive rövade bon.

${ }^{b}$ Excluded variables (Number of fledglings: $b=0.00048, p=0.99$; Proportion abandoned nests: $b=0.041, p=0.66$ ) did not significantly contribute to the variation in female return rate.

Utes/utna variabler (antal flygga: $b=0,00048, p=0,99$; andel övergivna bon: $b=0,041, p=0,66$ ) bidrog inte signifikant till att förklara variationen i andelen återvändande honor.

c Excluded variable (Proportion abandoned nests: $b=-0.031 ; p=0.88$ ) did not significantly contribute to the variation in female return rate. Utesluten variabel (andel övergivna bon: $b=0,031, p=0,88$ ) bidrog inte signifikant till att förklara variationen i andelen återvändande honor. ${ }^{d}$ Excluded variable (Number of fledglings: $b=0.049 ; p=0.26$ ) did not significantly contribute to the variation in male return rate. Utes/uten variabel (antal flygga: $b=0,049, p=0,26$ ) bidrog inte signifikant till att förklara variationen i andelen återvändande hannar.

weight of the males and brood size (Pearson's correlation: $\mathrm{r}=-0.21, \mathrm{p}<0.30, \mathrm{n}=26$ ). Increased reproductive effort, as a consequence of bigger broods, did obviously not influence survival rate of the females. Kern et al. (2014) found that the return rates of both females and males showed a significant positive relationship with nesting success. As judged from the description of their study site, the environmental conditions in Wales were certainly less harsh for breeding Pied Flycatchers than for those breeding in the northern Swedish mountains.

\section{RETURN RATE FOLLOWING THE SECOND BREEDING SEASON}

The return rates of females and males that had bred twice or more in the study area were significantly higher than for those that had bred there only once. The same pattern is regularly observed in different parts of the range of the species, e.g. in southern Finland (von Haartman 1951), western Germany (Winkel 1982), southern Sweden (Nilsson 2008), and Russia (the Courish Spit, southeastern Baltic coast; Chernetsov et al. 2009).

Measured over the whole study period (1965-2018), the average yearly return rates of females to Year X+2 (age $4 \mathrm{CY}+$ ) were about $40 \%$ (Table 6). Similar rates were presented by Winkel (1982) in 1974-1980, Nilsson (2008) in 1986-2005, and Chernetsov et al. (2009) in 1982-2006. von Haartman (1951) reported that $52 \%$ of the females returned for their third breeding in 19411949, which was at the same level as during the first decade, 1965-1976, of the present study, $53 \%$ (Table 6). During 1977-2018, the rates were significantly lower, on average $32 \%$.

It seems to be generally accepted that female and male Pied Flycatchers returning to their former breeding area for a third time (Year $\mathrm{X}+2$ ), around $40-50 \%$, continue to do so for the rest of their lives. If so, that would mean that these return rates then equal survival rates (cf. e.g. von Haartman 1951, Winkel 1982, Nyholm \& Myhrberg 1983, Nilsson 2008, Chernetsov et al. 2009). The present study, the most comprehensive as to numbers of breeding seasons, ringed, and recaptured individuals (Appendices 2 and 3), enables a more differentiated view of return rates and their variations over time. Thus, a significant decrease in return rates appeared for the $4 \mathrm{CY}+$ females after the mid-seventies, 
TABLE 6. Return rates (\%) and numbers (in brackets) of Pied Flycatcher females and males ringed $1965-2014{ }^{1}$ and 1965-1983, respectively, that returned a second, third, and fourth time.

- Andel (\%) och antal (inom parentes) honor och hannar av svartvit flugsnappare, ringmärkta 1965-2014 resp. 1965-1983, som återvände en andra, tredje och fjärde gång.

\begin{tabular}{|c|c|c|c|c|c|c|c|c|c|}
\hline \multirow{3}{*}{$\begin{array}{l}\text { Sex Kön } \\
\text { O }\end{array}$} & \multirow{3}{*}{$\begin{array}{l}\text { Period } \\
1965-2014^{1}\end{array}$} & \multicolumn{8}{|c|}{ Return rate Andel återvändare } \\
\hline & & \multicolumn{2}{|c|}{ Year $X+1$ to $X+2$} & \multicolumn{2}{|c|}{ Year $X+2$ to $X+3$} & \multicolumn{2}{|c|}{ Year $X+3$ to $X+4$} & \multicolumn{2}{|l|}{ Total } \\
\hline & & $40 \%$ & $(114 / 281)^{a}$ & $38 \%$ & $(42 / 111)$ & $28 \%$ & $(11 / 40)^{b}$ & $38 \%$ & (167/443) \\
\hline ㅇ & 1965-1976 & $53 \%$ & $(62 / 118)^{c}$ & $37 \%$ & $(23 / 62)^{d}$ & $30 \%$ & $(7 / 23)$ & $44 \%$ & $(92 / 210)^{n}$ \\
\hline 우 & $1977-1988^{2}$ & $30 \%$ & $(26 / 85)^{e}$ & $39 \%$ & $(9 / 23)$ & $57 \%$ & $(4 / 7)$ & $33 \%$ & $(39 / 119)^{\circ}$ \\
\hline 우 & 1995-2003 & $36 \%$ & $(9 / 25)^{f}$ & $56 \%$ & $(5 / 9)$ & $0 \%$ & $(0 / 5)$ & $36 \%$ & $(14 / 39)^{p}$ \\
\hline 우 & 2004-2014 & $32 \%$ & $(17 / 53)^{g}$ & $29 \%$ & $(5 / 17)$ & $0 \%$ & $(0 / 5)$ & $29 \%$ & $(22 / 75)^{q}$ \\
\hline $0^{x}$ & 1965-1983 & $35 \%$ & $(107 / 310)^{\mathrm{h}}$ & $62 \%$ & $(66 / 107)^{i}$ & $42 \%$ & $(28 / 66)^{j}$ & $39 \%$ & $(201 / 511)$ \\
\hline 우 & $1965-1983$ & $48 \%$ & $(78 / 163)^{k}$ & $35 \%$ & $(27 / 78)^{\prime}$ & $37 \%$ & $(10 / 27)^{m}$ & $41 \%$ & $(115 / 278)$ \\
\hline
\end{tabular}

1'Excluding 1989-1994. Exklusive 1989-1994.

${ }^{2}$ Five females were killed during nest predation in 1987-1988. Fem honor dödades vid bopredation under 1987-1988.

a-a Significance levels of $\chi^{2}$ tests between return rate categories Signifikansnivåer för $\chi^{2}$-test mellan kategorier av andel återvändare a-b: $p<0.05 ; c-d: p<0.001 ; c-(e+f+g): p<0.001 ; h-i: p<0.001 ; i-j: p<0$ 02; h-k: $p<0.001 ; i-l: p<0.001 ; k-(1+m): p<0.06$; $n-(o+p+q): p=0.01$.

from on average about $50 \%$ to a rather stable level at $30-36 \%$ in the following decades (Table 6). My interpretation is that the decrease was due to increased mortality during migration and/or at the overwintering sites, rather than to reduced innate fidelity to the former repeatedly used breeding area, or that returning females more often failed to breed and thereby remained unidentified.

During the seasons 1965-1985, when the return rates of females and males in Year $\mathrm{X}+2$ to $\mathrm{X}+4$ could be compared, the rates of the females decreased, while the males' return rate remained stable. This indicates that the suggested increased extra-seasonal mortality especially affected females.

It seems probable that also the significant reduction of females that returned from Year X to Year X+1 in 1965-1985 and continuously to 2018, at least partly, was due to increased mortality rate (Figure 1a). The different trends of return rate shown by the sexes from Year X to Year X+1 might be related to their opposite relations to breeding success (Table 4 ).

The significantly increased return rate of males, but not females, from Year $\mathrm{X}+2$ to Year $\mathrm{X}+3$ (age $5 \mathrm{CY}+$, $62 \%$; Table 6) disagrees with the generally accepted opinion that males and females, after having returned a second time to the former breeding site, continue to do so life-long (see above). The relatively low male return rate in Year $\mathrm{X}+2$ (age $4 \mathrm{CY}+; 35 \%$; Table 6) is probably explained by the fact that a part of the males that returned in Year $\mathrm{X}+1$ were still not fully faithful to their former breeding site. That seems a more probable explanation than that the mortality rate of males aged $4 \mathrm{CY}+$ was higher than that of the older $5 \mathrm{CY}+$ males. The reduced return rates shown by the $5 \mathrm{CY}+$ and older females, and by $6 \mathrm{CY}+$ males (Table 6) might be a consequence of senescence.

In conclusion, the pattern of lower return rate by Pied Flycatcher females than by males after having bred once in the study area was in agreement with results from other studies. That was also valid for the strongly increased return rates after having bred twice in both sexes, up to about similar levels.

By its extent, as to the length and number of ringed individuals, the present study could unambiguously show a decreasing return rate of the females of different ages during the latest five decades. The decrease is suggested to be due to increased mortality rate in females outside the breeding seasons. The established return rate decrease occurred in parallel with reductions of the breeding population (Nyholm 2011), suggesting that these events were related. The return rates of both sexes were also related to variations of local factors at the breeding site. Nest predation rate and breeding success influenced return rate of females and males differently. 


\section{Acknowledgements}

The study was initially supported by grants from Swedish Natural Research Council to Prof. Anders Enemar, and in several seasons from Alvins fond. Thanks are due to all field workers who helped to collect data and, not least, to Jan-Åke Nilsson for constructive comments on the manuscript, and help to evaluate data according to statistical practice.

\section{References}

Askenmo C. 1979. Reproductive effort and return rate of male Pied Flycatchers. American Naturalist 114: 748-753. https://doi. org/10.1086/283523

Chernetsov N, Sokolov LV \& Kosarev V. 2009. Local survival rates of Pied Flycatchers Ficedula hypoleuca depend on their immigrant status. Avian Ecology and Behaviour 16: 11-20.

Enemar A, Sjöstrand B, Andersson G \& von Proschwitz T. 2004. The 37-year dynamics of a subalpine passerine community, with special emphasis on the influence of environmental temperature and Epirrita autmnalis cycles. Ornis Svecica 14: 63-106. https://doi. org/10.34080/os.v14.20236

Haartman L von. 1951. Der Trauerschnäpper. II Populationsprobleme. Acta Zoologica Fennica Vol. 67.

Järvinen A. 1993. Spatial and temporal variation in reproductive trait of adjacent northern Pied Flycatcher Ficedula hypoleuca populations. Ornis Scandinavica 24: 33-40. https://doi. org/10.2307/3676407
Kern M, Slater F \& Cowie R. 2014. Return rate and dispersal distances of Welsh Pied Flycatchers Ficedula hypoleuca and that influence them. Ringing \& Migration, 29: 1-9. https://doi.org/10.108 o/03078698.2014.932617

Leivits A \& Vilbaste H. 1990. Breeding area fidelity and natal dipersal of the Pied Flycatcher in south-west Estonia. In Viksne J \& Vilks J. (eds): Baltic Birds 5. Proceeding of the fifth conference on the study and conservation of migratory birds of the Baltic Basin 1: 254-257.

Lundberg A \& Alatalo RV. 1992. The Pied Flycatcher. T\&AD Poyser, London.

Nilsson J-E. 2008. A 20-year study of a nest box breeding bird population with special regard to the Pied Flycatcher Ficedula hypoleuca. Ornis Svecica 18: 52-64. https://doi.org/10.34080/os.v18.20235

Nyholm NEI. 1984. Polygyny in the Pied Flycatcher Ficedula hypoleuca at Ammarnäs, Swedish Lapland. Annales Zoologici Fennici 21: 229-232.

Nyholm NEI. 1986. Birth area fidelity and age of first breeding in a northern population of Pied Flycatcher Ficedula hypoleuca. Ornis Scandinavica 17: 249-252. https://doi.org/10.2307/3676834

Nyholm NEI. 2011. Dynamics and reproduction of a nest box breeding population of Pied Flycatchers Ficedula hypoleuca in a subalpine birch forest in Swedish Lapland during a period of 46 years. Ornis Svecica 21: 133-156. https://doi.org/10.34080/os.v21.20232

Nyholm NEI. \& Myhrberg H. 1983. Breeding area fidelity of the Pied Flycatcher Ficedula hypoleuca at Ammarnäs, Swedish Lapland. Ornis Fennica 6o: 22-27.

Sanz JJ. 2001. Latitudinal variation in female local return rate in the philopatric Pied Flycatcher (Ficedula hypoleuca). Auk 118: 539-543. https://doi.org/10.2307/4089818

Winkel W. 1982. Zum Ortsteue-verhalten des Trauerschnäppers (Ficedula hypoleuca) im westlichen Randbereich seines mitteleuropäischen Verbreitungsgebietes. Journal für Ornithologie. 123: 155-173. https://doi.org/10.1007/BFo1645055

\section{Svensk sammanfattning}

Ortstroheten till häckningsområdet i fjällbjörkskog vid Ammarnäs i Lappland studerades hos ringmärkta honor av svartvit flugsnappare 1965-2018 och hos hannar 1965-1991. Totalt sett återvände 7,5 \% av honorna från sin första häckningssäsong i området till den andra. Trettioåtta procent av dessa fortsatte att återvända de tre därpå följande säsongerna. För hannarna var motsvarande andelar $27 \%$ resp. $39 \%$. Andelen honor som återvände för första gången minskade under åren med $30 \%$, från 9,5 \% under undersökningens första decennium. Också under åren 1966-1991 minskade andelen återvändande honor, medan hannarna i stället återvände i högre grad. Minskande trend gällde också för andelen honor som återvände en andra gång, från $53 \%$ under första decenniet till i genomsnitt $32 \%$ senare år.

Jag föreslår att skillnaden till stor del beror på att ökad dödlighet selektivt drabbat honorna utanför häckningssäsongen sedan slutet av 1970-talet. Lokala faktorer påverkade de årliga variationerna hos andelarna återkommande honor och hannar. Påverkan skilde sig mellan könen. Sålunda var andelen återkommande honor positivt relaterad till häckningsframgång och negativt till bopredation (av vesslor) föregående säsong. Anmärkningsvärt är att andelen hannar som återkom påverkades omvänt - var negativt relaterad till häckningsresultatet och gynnades av högre predationsfrekvens. Predationsfrekvensen var den av faktorerna som bäst förklarade variationerna mellan åren av både honors och hannars återkomst.

\section{METODER}

Studierna gjordes 1965-2018 i holkhäckande populationer 500-600 m ö.h. i fjällbjörkskog (se appendix 1) på sydsluttningarna av fjällen Gájssietjåhkka och 
Vállienjuoná 5-10 km väster om Ammarnäs, Lappland. Holkarna var placerade i biotoper som var stabila under undersökningstiden och som var likartade över ett betydligt större område. Den naturliga populationen av svartvit flugsnappare visade minskande trend under åren, från ca 15 till 5 par $/ \mathrm{km}^{2}$ (Enemar 2004).

Studien omfattar 4178 honor ringmärkta 1965-2017 (appendix 2) och 1565 hannar märkta 1965-1990 (appendix 3). I dessa antal ingår inte honor och hannar som dog (t. ex. på grund av predation i boet) under deras första häckningssäsong i holkarna. De ringmärkta fåglarna utgjordes varje år av en slumpvis fångad del av populationen. För att uppnå en så nära som möjligt korrekt skattning av antalet återvända individer, t. ex. från året de ringmärktes (år X) till nästföljande år (år X+1) beräknades en korrektionsfaktor: antalet häckande år X +1 dividerat med antalet fångade år $\mathrm{X}+1$. Korrektionsfaktorn multiplicerad med det konstaterade antalet märkta år X som återfångades år X+1 betraktas som det verkligt återvända antalet år X+1. Vid beräkning av korrektionsfaktorn för hannar sattes det häckande antalet $9 \%$ lägre än för honor på grund av polygyni i populationen. Bon med minst ett ägg noterades som häckning.

Honor fångades och ringmärktes till ca $90 \%$ under ruvningsperioden, de övriga under matning av ungarna. Hanarna ringmärktes till mer än $95 \%$ under ungperioden. Sålunda görs alla beräkningar avseende återvändande honor och hannar med fullvärpta kullar. Detta gäller också vid beräkningar av frekvenser av bopredation, övergivna bon och antal flygga ungar.

\section{RESULTAT}

\section{Andelen återvändande individer}

efter att ha häckat en gång i området

Andelen honor som återvände till häckningsområdet från säsongen de ringmärktes (år X) till den efterföljande (år X+1) var i genomsnitt 7,5\% under 1965-2018. Variationen mellan säsongerna var stor, o-19\% (tabell 1). Andelen minskade under perioden $(p<0,03)$, särskilt påtagligt under de första decennierna (figur 1a). Andelen hannar som återvände var betydligt större, $27 \%$, under de år de studerades (1965-1991; tabell 2). I motsats till honorna återvände en ökande andel av hannarna $(\mathrm{p}<0,008)$. Dessutom var de årliga variationerna för andelarna återkommande hannar respektive honor negativt korrelerade, $\mathrm{p}=0,04$.

Årliga andelar honor och hannar som återvände från år X till år X+1 studerades i relation till tre starkt varierande lokala faktorer: Häckningsframgång (antal utflugna ungar), andel rövade bon (spegling av antal predatorer i häckningsområdet) och andel övergivna bon (förutom rövade; återspeglar perioder med olämpligt väder; tabell 3). Andelen honor som återvände var positivt korrelaterad till häckningsframgång medan den var negativt relaterad till andel rövade bon säsongen före (tabell 4). Samma korrelationsmönster gällde för honorna 1966-1991 som under 1966-2018. Mönstret för hannarna 1966-1991 var motsatt det för honorna (tabell 4). När de årliga andelarna återvändande honor 1966-2018 testades mot alla tre häckningsfaktorerna tillsammans visade det sig att endast andelen rövade bon hade betydande inverkan (tabell 5). Även om andel rövade bon var relativt låg undre 1965-1990 påverkades andelarna återvändande honor såväl som hannar signifikant (tabell 5).

\section{Andel återvändande individer}

som häckat $i$ undersökningsområdet mer än en gång

Andelen honor som återvände från år X+1 till år X+2 tenderade att minska under den studerade perioden. Liksom för honor som återvände efter en häckningssäsong beskrevs trenden bäst av den kubiska regressionsmodellen (figur 1b). Medelandelen honor som ringmärktes 1965-2014 och häckade i området Åren X+2 till X+4 var $38 \%$ (tabell 6). Av honorna som ringmärktes under 1965-1976 häckade $44 \%$ åter, medan endast $29 \%$ av de som märktes 2004-2014 återvände. Högst andel, $53 \%$, uppvisade honor ringmärkta 1965-1976 och som återvände från år X+1 till år X+2. Honor ringmärkta senare återvände i betydande lägre grad ( $32 \%$; tabell 5). Hos honorna ringmärkta 1965-1976 framträdde en sannolikt åldersrelaterad minskning av andelarna återvändande, $53 \%, 37 \%$ och $30 \%$ för individer som var $4 \mathrm{~K}+, 5 \mathrm{~K}+$ respektive $6 \mathrm{~K}+$.

Andelarna honor och hannar som ringmärktes 19651983, och som återvände år X+2 till X+4, var på samma nivå, $41 \%$ respektive $39 \%$. För hannarna ökade andelen återvändande signifikant från år X+1 (25\%), över år $\mathrm{X}+2$ (35\%) till år X+3 (63\%), och minskade därefter till år X+4 (42\%). Först från år X+2 till år X+3 återvände hannar i större utsträckning än honor (tabell 6). 


\section{DISKUSSION}

\section{Andelen återvändande individer}

efter att ha häckat en gång $i$ området

Andelen återvändande honor från den första häckningssäsongen till nästa, 7,5\%, passar väl in i mönstret att andelen ökar från nordliga till sydliga breddgrader (se Sanz 2001). Hanar återvänder vanligtvis i större utsträckning än honor. Också hannarna uppvisade lägre andel $(27 \%)$ än vad som vanligtvis rapporterats från sydligare områden (jfr Lundberg \& Alatalo 1992).

Den minskande andelen återvändande honor under 1966-1991, den ökande andelen återvändande hannar samma period, samt den negativa korrelationen mellan de årliga andelarnas variation hos könen tolkas som att faktorer, externa eller lokala på häckningsplatsen, påverkade återvändandegraden olika för honor och hannar. Lokala faktorer som potentiellt bedömdes påverka andelen återvändande individer studerades: häckningsresultat, andel rövade bon och andel övergivna bon. De två sistnämnda påverkade häckningsframgången kraftigt och bidrog till att hindra populationen av svartvit flugsnappare att vara långsiktigt självreproducerande ( $\mathrm{Ny}-$ holm 2011). Bopredationen, av små mårddjur, varierade kraftigt och var relaterad till tätheten hos de cykliska smågnagarpopulationerna, som typiskt förekommer i norra Skandinavien. Det nordliga och högt belägna undersökningsområdet innebar också ökad risk för perioder av ogynnsamt väder under häckningssäsongen. De årliga andelarna övergivna bon var signifikant korrelerade med junitemperaturen. Dessa faktorer visade sig påverka andelarna återvändande honor och hannar, men olika för könen (tabell 4; se också Kern et al. 2014).

Analys av de lokala faktorerna tillsammans angav att endast andelen rövade bon påverkade andelen återkommande honor signifikant under 1965-2017, då bopredationen genomsnittligt drabbade flest bon (tabell 5). Det noteras att även under perioden 1965-1986, då bopredation drabbade betydligt färre, var det den av faktorerna som var starkast relaterad till andelen återvändande honor. Även andelen övergivna bon hade då signifikant påverkan. Detta antyder att variationen av andelen återvändande honor var negativt relaterad till andelen totalt förlorade kullar av ägg/ungar. Variationen hos årliga andelen återvändande hannar under motsvarande period var inte signifikant relaterad till någon av de studerade lokala faktorerna.
Variationen av andelen hannar som återvände, såväl som honor, var under 1965-1990 signifikant förklarad av andelen rövade bon (tabell 5). Medan bopredationen påverkade andelen återvändande honor negativt hade den en positiv inverkan på andelen återvändande hannar (tabell 4). Större predationsfrekvens medför reducerad häckningsprestation. Askenmo (1979) påvisade, i södra Sverige, att experimentellt ökad kullstorlek följdes av minskad andel återkommande hannar. Det tolkades som att den extra ansträngning som förstorade ungkullar innebar ledde till ökad dödlighet under flyttning/övervintring. En förklaring till den negativa relationen mellan andelen återvändande hannar och antalet flygga ungar i den subalpina biotopen kan vara, att ansträngningen även vid normala kullstorlekar blir tillräckligt stor, vid de ofta svåra häckningsförhållanden som råder, för att hannars överlevnad skall påverkas. Stora årliga förluster av boungar under 1965-1990 (tabell 3) antyder svårigheter att tillfredsställa deras behov av mat.

\section{Andelen återvändande individer}

efter två eller fler häckningssäsonger i området

Andelarna återvändande honor och hannar som häckat två eller fler gånger i undersökningsområdet var betydlig större än för de som endast häckat en gång tidigare. Detta är gemensamt med vad som gäller i andra delar av artens utbredningsområde. Det synes vara allmänt vedertaget att honor och hannar som återkommer en tredje gång (år X+2; ålder $4 \mathrm{~K}+$ ), 40-50\%, fortsätter att återvända så länge de lever. Denna andel skulle vara mått på överlevnaden. Genom den långa undersökningsperioden, det stora antalet ringmärkta och kontrollerade individer kan en mer differentierad bild ges av andelen återkommande individer och hur den varierat över tiden. En betydligt minskad andel $4 \mathrm{~K}+$-honor återkom efter mitten av 1970-talet, från ca 50 \% till en ganska stabil nivå vid 30-36\% de följande decennierna (tabell 6; figur $1 \mathrm{~b}$ ). Denna minskning tolkas bero på ökad dödlighet mellan häckningssäsongerna, snarare än reducerad ortstrohet till häckningområde som använts flera säsonger, eller att fler honor blev oidentifierade på grund av utebliven eller misslyckad häckning.

Under 1965-1985, då andelarna återvändande honor och hannar under år X+2 till år X+4 kunde jämföras, minskade andelarna honor medan andelen återvändande hannar förblev på jämn nivå. Detta antyder att den 
ökade dödligheten mellan häckningssäsongerna speciellt drabbade honor. Det verkar sannolikt att den betydande minskningen av andelen honor som återvände från år X till år X+1 (figur 1a) liksom minskningen från år X+1 till år X+2 under 1965-1985 och fortsättningsvis till 2018 (figur 1b), berodde på ökad dödlighet. De olika trender som andelarna återvändande honor respektive hannar uppvisar skulle kunna sammanhänga med deras skilda relation till häckningsresultat (tabell 4-5).

Den betydande ökning av andelen återkommande hannar, men inte honor, som förekom från år X+2 till år X+3 (ålder $5 \mathrm{~K}+$; tabell 6) motsäger den allmänt accepterade hypotesen att hannar såväl som honor som återvänt en andra gång för att häcka i samma område fortsätter livslångt. Den relativt låga andel hannar som återkom från år X+1 till år X+2 (ålder $4 \mathrm{~K}+; 35 \%$; tabell 6) har sannolik förklaring $i$ att en andel av hannarna som återkom år X+1 då ännu inte var helt trogna sitt förra häckningsområde.

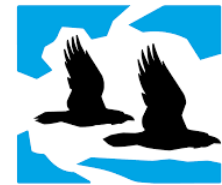

BirdLife Sverige

Ornis Svecica (ISSN 2003-2633) is an open access, peer-reviewed scientific journal published in English and Swedish by BirdLife Sweden. It covers all aspects of ornithology, and welcomes contributions from scientists as well as non-professional ornithologists. Accepted articles are published at no charge to the authors. Read papers or make a submission at https://os.birdlife.se.

Ornis Svecica (ISSN 2003-2633) är en fritt tillgänglig granskad vetenskaplig tidskrift som ges ut på svenska och engelska av BirdLife Sverige. Den täcker ornitologins alla områden och välkomnar bidrag från såväl forskare som icke-professionella ornitologer. Accepterade uppsatser publiceras utan kostnad för författarna. Läs uppsatser eller skicka in ditt bidrag på https://os.birdlife.se. 


\section{Appendix 1. Habitat types}
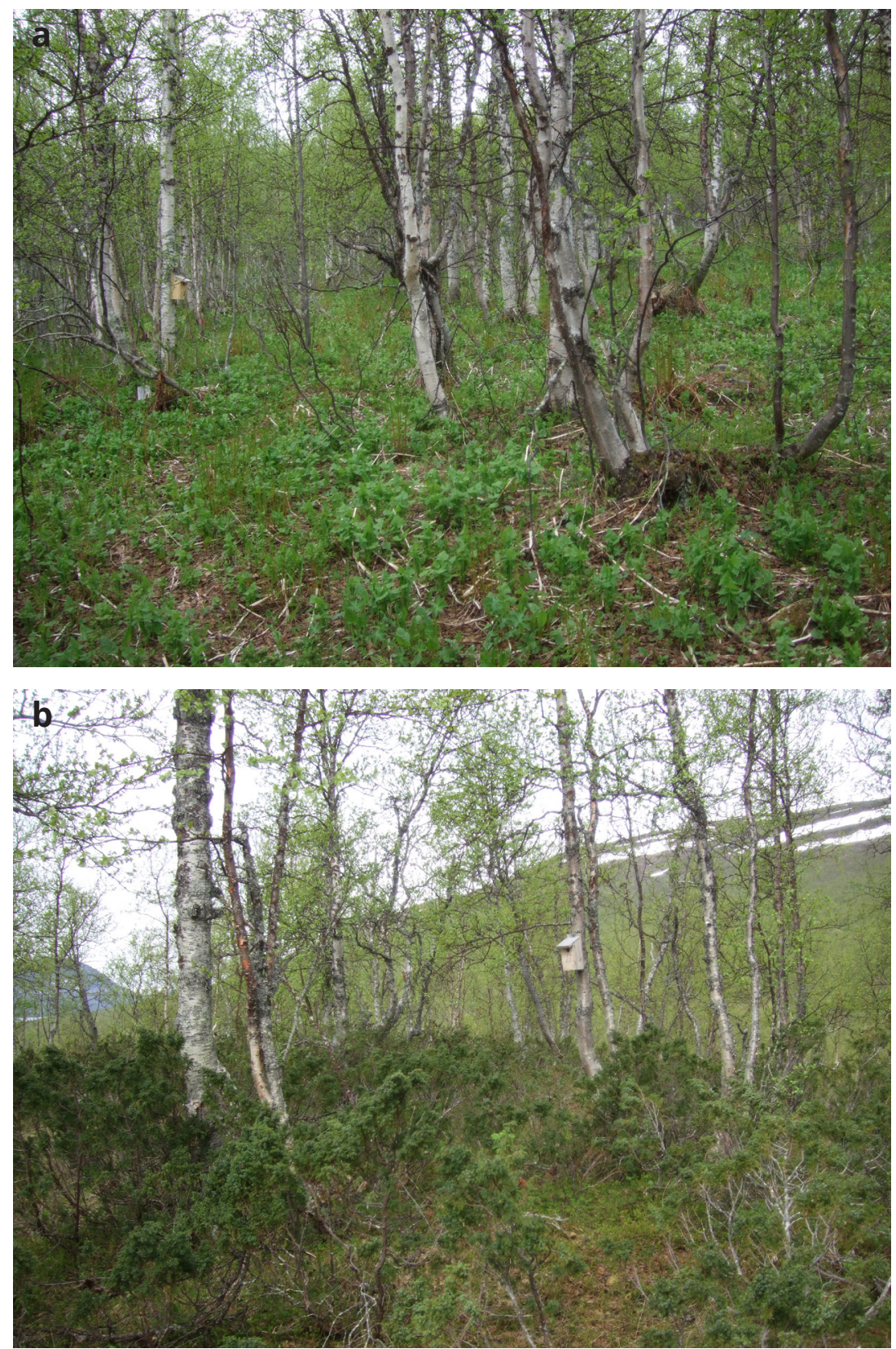

Birch forest of (a) meadow type and (b) heath type, a few days after leafing, on the southern slope of the mountain Gájssietjåhkka, 16 May 2010. Most Pied Flycatchers were incubating at the time. Photo: Erik Nyholm.

Björkskog av (a) ängstyp och (b) hedtyp, kort efter lövsprickning, på fjället Gájssietjåhkkas syds/uttning, 16 maj 2010. Vid fototillfället hade flertalet svartvit flugsnappare börjat ruva. Foto: Erik Nyholm. 


\section{Appendix 2. Number of studied females, 1965-2018}

\begin{tabular}{|c|c|c|c|c|c|c|c|c|c|c|c|c|}
\hline \multirow[b]{3}{*}{$\begin{array}{l}\text { Year X } \\
\operatorname{Ar} X\end{array}$} & \multicolumn{4}{|c|}{$\begin{array}{c}\text { Number of females Year X } \\
\text { Antal honor år } X\end{array}$} & \multicolumn{8}{|c|}{$\begin{array}{l}\text { Number of returning females } \\
\text { Antal återvändande honor }\end{array}$} \\
\hline & \multirow[b]{2}{*}{$\begin{array}{l}\text { Breeding } \\
\text { Häckande }\end{array}$} & \multirow{2}{*}{\multicolumn{2}{|c|}{$\begin{array}{l}\text { Captured } \\
\text { Fångade }\end{array}$}} & \multirow{3}{*}{$\begin{array}{l}\begin{array}{l}\text { Ringed } \\
\text { Ringmärkta }\end{array} \\
89\end{array}$} & \multicolumn{4}{|c|}{ Verified Konstaterat } & \multicolumn{4}{|c|}{ Calculated Beräknat } \\
\hline & & & & & $\underset{\mp}{ \pm}$ & $\stackrel{\stackrel{+}{ \pm}}{\times}$ & $\stackrel{m}{\stackrel{m}{x}}$ & $\stackrel{+}{\stackrel{+}{x}}$ & $\underset{+}{+}$ & $\stackrel{\stackrel{N}{ \pm}}{x}$ & $\underset{\stackrel{m}{\times}}{\stackrel{m}{+}}$ & $\stackrel{+}{\underset{x}{+}}$ \\
\hline 1965 & 100 & 89 & $(89 \%)$ & & 5 & 2 & 1 & 0 & 5 & 3 & 1 & 0 \\
\hline 1966 & 77 & 71 & $(92 \%)$ & 66 & 7 & 2 & 1 & 1 & 10 & 2 & 1 & 1 \\
\hline 1967 & 105 & 75 & $(71 \%)$ & 62 & 5 & 4 & 0 & 0 & 6 & 5 & 0 & 0 \\
\hline 1968 & 114 & 96 & $(84 \%)$ & 84 & 10 & 5 & 1 & 0 & 12 & 6 & 1 & 0 \\
\hline 1969 & 151 & 129 & $(85 \%)$ & 112 & 7 & 5 & 3 & 1 & 9 & 7 & 4 & 1 \\
\hline 1970 & 186 & 149 & $(80 \%)$ & 133 & 9 & 4 & 2 & 1 & 12 & 5 & 3 & 1 \\
\hline 1971 & 191 & 138 & $(72 \%)$ & 119 & 4 & 2 & 0 & 0 & 5 & 3 & 0 & 0 \\
\hline 1972 & 155 & 115 & $(74 \%)$ & 101 & 13 & 12 & 4 & 0 & 18 & 15 & 6 & 0 \\
\hline 1973 & 183 & 133 & $(73 \%)$ & 111 & 10 & 5 & 2 & 3 & 12 & 7 & 2 & 4 \\
\hline 1974 & 216 & 177 & $(82 \%)$ & 150 & 10 & 3 & 1 & 0 & 14 & 3 & 1 & 0 \\
\hline 1975 & 192 & 135 & $(70 \%)$ & 110 & 3 & 1 & 0 & 0 & 3 & 1 & 0 & 0 \\
\hline 1976 & 114 & 105 & (92\%) & 94 & 10 & 4 & 2 & 0 & 12 & 5 & 4 & 0 \\
\hline 1977 & 161 & 133 & (83\%) & 100 & 6 & 0 & 0 & 0 & 8 & 0 & 0 & 0 \\
\hline 1978 & 159 & 122 & $(77 \%)$ & 109 & 2 & 2 & 1 & 1 & 4 & 2 & 1 & 2 \\
\hline 1979 & 202 & 104 & (51\%) & 95 & 3 & 0 & 0 & 1 & 4 & 0 & 0 & 1 \\
\hline 1980 & 136 & 113 & (85\%) & 110 & 9 & 3 & 1 & 0 & 13 & 5 & 1 & 0 \\
\hline 1981 & 185 & 132 & (71\%) & 116 & 3 & 3 & 1 & 0 & 5 & 4 & 1 & 0 \\
\hline 1982 & 179 & 117 & $(65 \%)$ & 106 & 4 & 2 & 0 & 0 & 5 & 2 & 0 & 0 \\
\hline 1983 & 171 & 129 & $(75 \%)$ & 113 & 5 & 2 & 1 & 0 & 6 & 3 & 1 & 0 \\
\hline 1984 & 135 & 118 & $(87 \%)$ & 109 & 9 & 0 & 2 & 0 & 14 & 0 & 4 & 0 \\
\hline 1985 & 147 & 97 & $(66 \%)$ & 80 & 12 & 3 & 0 & 0 & 15 & 6 & 0 & 0 \\
\hline 1986 & 205 & 169 & (51\%) & 144 & 6 & 1 & 1 & 1 & 11 & 3 & 1 & 1 \\
\hline 1987 & 233 & 118 & (51\%) & 93 & 0 & 0 & 0 & 0 & 0 & 0 & 0 & 0 \\
\hline 1988 & 155 & 48 & (31\%) & 42 & 0 & 1 & 0 & 0 & 0 & 1 & 0 & 0 \\
\hline 1989 & 138 & 93 & $(67 \%)$ & 91 & 6 & 4 & 1 & 0 & 7 & 6 & 2 & (0) \\
\hline 1990 & 138 & 120 & $(87 \%)$ & 109 & 7 & 1 & 0 & 0 & 10 & 2 & (0) & (0) \\
\hline 1991 & 127 & 91 & (72\%) & 77 & 6 & 0 & 0 & 0 & 11 & (0) & (0) & (0) \\
\hline 1992 & 140 & 74 & (53\%) & 66 & 0 & 0 & 0 & 0 & (0) & (4) & (0) & (0) \\
\hline 1993 & 119 & 19 & $(16 \%)$ & 19 & 1 & 0 & 0 & 0 & (4) & (0) & (0) & (0) \\
\hline 1994 & 80 & 19 & $(24 \%)$ & 17 & 0 & 0 & 0 & 0 & (0) & (0) & (0) & (0) \\
\hline 1995 & 79 & 47 & (59\%) & 47 & 1 & 2 & 0 & 0 & 2 & 3 & 0 & 0 \\
\hline 1996 & 92 & 52 & (57\%) & 52 & 4 & 1 & 2 & 0 & 7 & 2 & 3 & 0 \\
\hline 1997 & 127 & 73 & (57\%) & 66 & 1 & 1 & 1 & 0 & 2 & 2 & 2 & 0 \\
\hline 1998 & 96 & 52 & $(54 \%)$ & 50 & 0 & 0 & 0 & 0 & 0 & 0 & 0 & 0 \\
\hline 1999 & 105 & 64 & (61\%) & 59 & 2 & 0 & 0 & 0 & 5 & 0 & 0 & 0 \\
\hline 2000 & 114 & 48 & $(42 \%)$ & 43 & 2 & 0 & 0 & 0 & 3 & 0 & 0 & 0 \\
\hline 2001 & 83 & 58 & (70\%) & 56 & 2 & 1 & 0 & 0 & 3 & 2 & 0 & 0 \\
\hline 2002 & 84 & 55 & $(65 \%)$ & 53 & 0 & 0 & 0 & 0 & 0 & 0 & 0 & 0 \\
\hline 2003 & 119 & 58 & (49\%) & 56 & 2 & 0 & 0 & 0 & 3 & 0 & 0 & 0 \\
\hline
\end{tabular}


APPENDIX 2 continued fortsatt.

\begin{tabular}{|c|c|c|c|c|c|c|c|c|c|c|c|c|}
\hline \multirow[b]{3}{*}{$\begin{array}{l}\text { Year X } \\
\operatorname{Ar} X\end{array}$} & \multicolumn{4}{|c|}{$\begin{array}{c}\text { Number of females Year } X \\
\text { Antal honor år } X\end{array}$} & \multicolumn{8}{|c|}{$\begin{array}{l}\text { Number of returning females } \\
\text { Antal återvändande honor }\end{array}$} \\
\hline & \multirow[b]{2}{*}{$\begin{array}{l}\text { Breeding } \\
\text { Häckande }\end{array}$} & \multirow{2}{*}{\multicolumn{2}{|c|}{$\begin{array}{l}\text { Captured } \\
\text { Fångade }\end{array}$}} & \multirow[b]{2}{*}{$\begin{array}{l}\text { Ringed } \\
\text { Ringmärkta }\end{array}$} & \multicolumn{4}{|c|}{ Verified Konstaterat } & \multicolumn{4}{|c|}{ Calculated Beräknat } \\
\hline & & & & & $\underset{\mp}{\mp}$ & $\stackrel{\sim}{\stackrel{+}{x}}$ & $\stackrel{m}{\stackrel{m}{x}}$ & $\stackrel{+}{+}$ & $\underset{\mp}{\mp}$ & $\stackrel{\sim}{+}$ & $\stackrel{m}{\stackrel{m}{x}}$ & $\stackrel{+}{+}$ \\
\hline 2004 & 101 & 64 & $(63 \%)$ & 62 & 2 & 2 & 1 & 0 & 3 & 3 & 1 & 0 \\
\hline 2005 & 136 & 83 & $(61 \%)$ & 78 & 4 & 1 & 1 & 0 & 6 & 1 & 2 & 0 \\
\hline 2006 & 131 & 85 & $(65 \%)$ & 75 & 3 & 1 & 0 & 0 & 3 & 2 & 0 & 0 \\
\hline 2007 & 101 & 89 & (88\%) & 80 & 10 & 5 & 1 & 0 & 16 & 7 & 1 & 0 \\
\hline 2008 & 120 & 77 & $(64 \%)$ & 58 & 3 & 0 & 0 & 0 & 4 & 0 & 0 & 0 \\
\hline 2009 & 88 & 66 & (75\%) & 54 & 1 & 1 & 0 & 0 & 1 & 1 & 0 & 0 \\
\hline 2010 & 88 & 67 & (76\%) & 59 & 4 & 0 & 0 & 0 & 6 & 0 & 0 & 0 \\
\hline 2011 & 119 & 80 & (67\%) & 74 & 3 & 2 & 1 & 0 & 8 & 3 & 1 & 0 \\
\hline 2012 & 110 & 40 & (36\%) & 34 & 2 & 0 & 0 & 0 & 3 & 0 & 0 & 0 \\
\hline 2013 & 94 & 59 & $(63 \%)$ & 53 & 2 & 0 & 0 & 0 & 3 & 0 & 0 & 0 \\
\hline 2014 & 102 & 74 & $(73 \%)$ & 69 & 0 & 0 & 0 & 0 & 0 & 0 & 0 & 0 \\
\hline 2015 & 103 & 67 & $(65 \%)$ & 55 & 0 & 1 & 0 & & 0 & 2 & 0 & \\
\hline 2016 & 101 & 57 & (56\%) & 53 & 1 & 0 & & & 2 & 0 & & \\
\hline 2017 & 93 & 58 & $(62 \%)$ & 54 & 0 & & & & 0 & & & \\
\hline
\end{tabular}

Numbers in brackets are excluded from further calculations because of the low proportion of ringed and recaptured individuals in 1993-1994. Antal inom parentes används inte vid vidare beräkningar på grund av den låga andelen ringmärkta och kontrollerade individer 1993 och 1994. 


\section{Appendix 3. Number of studied males, 1965-1991}

\begin{tabular}{|c|c|c|c|c|c|c|c|c|c|c|c|c|c|c|c|c|}
\hline \multirow{4}{*}{$\begin{array}{l}\text { Year X } \\
\text { ArX } \\
1965\end{array}$} & \multicolumn{4}{|c|}{ Number of males Year X Antal hannar år X } & \multicolumn{12}{|c|}{ Number of returning males Antal återvändande hannar } \\
\hline & \multirow{3}{*}{$\begin{array}{c}\begin{array}{c}\text { Breeding } \\
\text { Häckande }\end{array} \\
91\end{array}$} & \multirow{2}{*}{\multicolumn{2}{|c|}{$\begin{array}{l}\text { Captured } \\
\text { Fångade }\end{array}$}} & \multirow{3}{*}{$\begin{array}{l}\begin{array}{l}\text { Ringed } \\
\text { Ringmärkta }\end{array} \\
78\end{array}$} & \multicolumn{6}{|c|}{ Verified Konstaterat } & \multicolumn{6}{|c|}{ Calculated Beräknat } \\
\hline & & & & & $\underset{+}{\mp}$ & $\stackrel{\stackrel{\sim}{*}}{x}$ & $\stackrel{m}{+}$ & $\underset{+}{\stackrel{+}{x}}$ & $\stackrel{\stackrel{n}{+}}{+}$ & $\begin{array}{l}\varphi \\
\stackrel{+}{x}\end{array}$ & $\underset{+}{\mp}$ & $\stackrel{\stackrel{\sim}{*}}{\underset{x}{x}}$ & $\stackrel{m}{+}$ & $\stackrel{+}{+}$ & $\stackrel{\stackrel{\varphi}{+}}{\underset{x}{x}}$ & $\begin{array}{l}0 \\
\stackrel{+}{x}\end{array}$ \\
\hline & & 78 & $(86 \%)$ & & 10 & 2 & 3 & 3 & 2 & 0 & 16 & 8 & 5 & 4 & 3 & 0 \\
\hline 1966 & 70 & 45 & $(64 \%)$ & 34 & 1 & 2 & 0 & 1 & 0 & 0 & 4 & 3 & 0 & 1 & 0 & 0 \\
\hline 1967 & 96 & 24 & $(25 \%)$ & 19 & 4 & 0 & 0 & 0 & 0 & 0 & 6 & 0 & 0 & 0 & 0 & 0 \\
\hline 1968 & 104 & 68 & $(65 \%)$ & 55 & 9 & 6 & 1 & 1 & 0 & 0 & 13 & 8 & 2 & 1 & 0 & 0 \\
\hline 1969 & 137 & 95 & (69\%) & 81 & 12 & 5 & 2 & 1 & 0 & 0 & 16 & 8 & 3 & 2 & 0 & 0 \\
\hline 1970 & 169 & & (73\%) & 99 & 14 & 6 & 3 & 1 & 1 & 1 & 23 & 8 & 5 & 1 & 2 & 1 \\
\hline 1971 & 174 & & (61 \%) & 80 & 12 & 7 & 1 & 1 & 1 & 0 & 17 & 11 & 1 & 2 & 1 & 0 \\
\hline 1972 & 141 & & (71 \%) & 71 & 10 & 6 & 2 & 1 & 0 & 0 & 16 & 9 & 5 & 1 & 0 & 0 \\
\hline 1973 & 167 & & (63\%) & 78 & 14 & 3 & 6 & 0 & 0 & 0 & 20 & 7 & 7 & 0 & 0 & 0 \\
\hline 1974 & 197 & & (70\%) & 110 & 14 & 6 & 5 & 1 & 0 & 0 & 32 & 7 & 10 & 2 & 0 & 0 \\
\hline 1975 & 175 & 76 & (43\%) & 50 & 9 & 0 & 1 & 0 & 0 & 0 & 11 & 0 & 2 & 0 & 0 & 0 \\
\hline 1976 & 104 & 84 & (81\%) & 51 & 10 & 2 & 1 & 1 & 0 & 0 & 20 & 3 & 3 & 1 & 0 & 0 \\
\hline 1977 & 147 & 74 & $(50 \%)$ & 58 & 8 & 2 & 4 & 2 & 1 & 0 & 13 & 7 & 5 & 5 & 3 & 0 \\
\hline 1978 & 145 & 88 & (61 \%) & 67 & 9 & 2 & 0 & 1 & 0 & 0 & 31 & 3 & 0 & 3 & 0 & 0 \\
\hline 1979 & 184 & 53 & (29\%) & 41 & 7 & 0 & 0 & 0 & 0 & 0 & 10 & 0 & 0 & 0 & 0 & 0 \\
\hline 1980 & 124 & 91 & $(73 \%)$ & 73 & 5 & 2 & 1 & 0 & 0 & 0 & 13 & 5 & 2 & 0 & 0 & 0 \\
\hline 1981 & 168 & 64 & (38\%) & 53 & 5 & 1 & 3 & 1 & 1 & 0 & 13 & 2 & 4 & 2 & 2 & 0 \\
\hline 1982 & 163 & 62 & (38\%) & 51 & 10 & 6 & 5 & 2 & 0 & 0 & 17 & 7 & 9 & 3 & 0 & (0) \\
\hline 1983 & 156 & 90 & (58\%) & 72 & 16 & 6 & 2 & 0 & 0 & 0 & 19 & 11 & 3 & 0 & (0) & (0) \\
\hline 1984 & 123 & & $(84 \%)$ & 74 & 5 & 6 & 1 & 0 & 1 & 0 & 9 & 9 & 8 & (0) & (3) & (0) \\
\hline 1985 & 134 & 71 & $(53 \%)$ & 49 & 7 & 1 & 0 & 0 & 0 & 0 & 11 & 8 & (0) & (0) & (0) & (0) \\
\hline 1986 & 187 & & $(64 \%)$ & 89 & 4 & 1 & 1 & 0 & 0 & & 30 & (11) & (3) & (0) & (0) & \\
\hline 1987 & 212 & 28 & (13\%) & 19 & 0 & 1 & 0 & 0 & & & (0) & (3) & (0) & (0) & & \\
\hline 1988 & 141 & 13 & (9\%) & 12 & 2 & 0 & 0 & & & & 6 & 0 & 0 & & & \\
\hline 1989 & 126 & 41 & (33\%) & 35 & 8 & 0 & & & & & 13 & 0 & & & & \\
\hline 1990 & 126 & 78 & $(62 \%)$ & 66 & 6 & & & & & & 35 & & & & & \\
\hline 1991 & 116 & 20 & (17\%) & & & & & & & & & & & & & \\
\hline
\end{tabular}

Numbers in brackets are excluded from further calculations because of the low proportion of ringed and recaptured individuals in $1993-1994$. Antal inom parentes används inte vid vidare beräkningar på grund av den låga andelen ringmärkta och kontrollerade individer 1993 och 1994. 